\title{
Verification of splitting queen - rearing technique at the backyards of beekeeping farmers in Wag-himra zone, Amhara Region, Ethiopia
}

\author{
Abebe Jenberie Wubie ${ }^{1, *}$, Muluken Girma ${ }^{2}$, Addisu Bihonegn ${ }^{1}$, Alubel Alemu ${ }^{1}$, \\ Meresa Lemma ${ }^{1}$ \\ ${ }^{I}$ Sekota Dry land Agricultural Research Center (SDARC), Sekota, Ethiopia \\ ${ }^{2}$ Wollo University, Desse, Ethiopia \\ *Abebe Jenberie Wubie is for whom correspondence (ajenberie@gmail.com) \\ Sekota Dry land Agricultural Research Center (SDARC) 62, Sekota, Ethiopia
}

\begin{abstract}
At present, due to various reasons, honeybee colony population is certainly in a state of continuous decline and absconding is becoming the major problem against beekeeping development. As a result, it is becoming more difficult to obtain adequate swarms every year to start and expand an apiary. Furthermore, farmers in the area are also complaining that they are facing serious shortage of honeybee colonies. Hence, mitigating the increasing demand of honeybee population using artificial queen rearing techniques is very critical at this moment. This, thus, had led to the implementation of splitting queen rearing technique verification under farmers' condition targeting testing the available splitting queen-rearing method in frame hives, setting the possible queen rearing calendar of local bees for future use and demonstrating splitting queenrearing technique for beekeepers. The experiment was implemented in two representative sites of the study area. From these sites 10 (in five replications) interested beekeepers were selected purposively. The experiment was then implemented following the appropriate procedures in splitting queen rearing technique for consecutive two years. Accordingly, the result has indicated that in areas, where honeybee feed shortage is paramount important and absconding is a peculiar characteristic to the beekeeping sub sector, colony multiplication could be done and used as a means of alleviating serious colony shortage with proper colony management. However, out of the total colonies in both sites, about $40 \%$ of the colonies have absconded only due to wax moth infestation aggravated by strong dearth and about 60\% of them were adapted. Consequently, local honeybee colonies in the area have been found to emerge an average of 8.6 queen cells with a maximum and minimum of 15 and 5 queen cells respectively. This in turn has elaborated that queen rearing with local honeybee colonies is also possible in the area. It also indicated that the possibility of having more than 8 colonies from a single properly prepared mother colony in the area. Honey produced from splitted colonies (mother and daughter) have advanced the production from non-splitted colonies owned by non-participant beekeepers with a $40.12 \%(65 \mathrm{~kg})$ yield increment. Thus, the experiment has revealed that participant beekeepers have benefited from the technology over the non-participant beekeeping farmers. Beekeepers have also realized that a yield decrease during splitting has been compensated in the following honey flow season. Regarding time of application, the result have confirmed that potential onset of flowering, just a week before peak natural swarming period, was appropriate with the use of strong mother colonies. The period starts from mid of August to last week of August in lower altitude areas and from last week of August to second week of September in middle altitude areas. Based on the results from the experiment, it has been recommended that splitting queen rearing technique could be further applied and utilized under farmers' condition in Wag-Lasta area and similar environments. Of course, provision of adequate practical training shall not be forgotten when thinking of colony multiplication in the area. Scaling up of the technology would be better if it is applied through small interest/business groups. Finally, for the advancement of the technology, the government should emphasize on awareness creation, organization of small interested/business groups, proper support and linking the system, even to marketing of live colonies.
\end{abstract}

Key Words: Splitting, queen rearing, participants, non-participants, beekeeping farmers, mother and daughter colonies, honey production, wax moth

\section{Introduction}

The basic sources of bee colonies for beekeeping beginner farmers around Wag-Lasta area are those wild bees (feral bees) found in areas where human rich is limited due to different reasons. Since an artificial queen rearing was not a practice and reported before in the area, beekeepers are expanding their apiaries and number of bee colonies simply by following the bees' natural reproduction pattern.

At present, due to various factors, honey bee colony population is in a state of continuous decline. Absconding is also becoming the major problem in beekeeping development and known to be a peculiar 
characteristic of the area. As the result, it is becoming more difficult to obtain adequate swarms every year to start and expand an apiary (Nuru and Dereje, 1999). In most cases, farmers in the area are also complaining for that they are facing serious shortage of honeybee colonies.

Moreover, there is a high demand for honeybee colonies mainly due to the involvement of individuals and different NGOs in beekeeping development. Consequently, the price of honeybee colonies is becoming too costly for beekeeping farmers to expand their bee farms and engage in beekeeping, even though it can be used as an income source for the others (Nuru and Dereje, 1999; Abebe, 2008).

Beekeepers in the area and other parts of the country believed that the rapid deforestation of honeybee plants around the area is the primary reason for the diminishing number of honeybee colonies (Abebe, 2008). Moreover, the drought existed for many years due to shortage of rainfall, is the other reason to aggravate the problem (Abebe, 2008).

In this area, where reproductive swarming tendency is low, one of the major problems of apiculture is obtaining swarms either to start or to increase the existing stock. Thus, development, verification and demonstration of simple ways of colony multiplication skills would be very important (Nuru and Dereje, 1999) and of these, splitting queen-rearing method have been rated as better in its simplicity for local conditions.

However, honeybees have their own breeding strategies which are very dependent on the potential of the queen and the general activeness of the worker bees in a colony (Laidlaw et al., 1962; Dan, 2006). These days, man has highly involved in facilitating and managing the breeding strategies of the colony (Snelgrove, 1981). Of course, there are different preconditions for successful queen breeding such as the presence of enough flowering plants, availability of fresh water, presence of plenty of young bees brood and store at exactly the right time, observed good behaviour of the colony, productivity of the colony, less tendency towards swarming, good record of gentleness, status of worker bees in nectar and pollen collection, availability of drones, availability of day old eggs, availability of necessary beekeeping accessories and equipments (Jay, 1923; Laidlaw et al., 1962; Snelgrove, 1981; Dan, 2006).

Even though the commercial lifespan of honeybee queen is two years, beekeepers in the area are not replacing their queens at this stage; rather they merely left the colony to replace the queen after she ends her actual life span through the natural queen rearing process (Jim Cameron, et al, 1984; Graham, 1992). Nevertheless, having old queen could result in the declining of the colony's productivity since the old queen couldn't administrate the colony efficiently (Jay, 1923; Snelgrove, 1981).

Thus, mitigating the satisfaction of the increasing demand of honeybee population by different newly emerging stakeholders through increasing the declining honeybee population using artificial queen rearing techniques is very critical at this moment (Jim Cameron, et al, 1984). This, thus, led us to verify and demonstrate the reliability of splitting queen rearing technique with regard to honeybee colony multiplication in frame hives under farmer's condition.

\section{Materials and Methods}

Activity 1: Sites, farmers and colony selection

Based on agro-ecology and the potential to beekeeping activity, two representative sites, Site A (midland) and Site B (lowland) were selected and at each site, five farmers, who have strong honeybee colony in frame hives with better experience, were purposively selected and were briefed with the objectives and outcomes of queen rearing activities including all the activities expected from them and the research group. Based on farmer's information and simple observations, one colony hived in a frame hive was assigned to this experiment from each of the selected farmers.

Activity 2: Colony assignment and experimentation

The selected colonies were then assigned to splitting queen-rearing technique in five replications within the site. Therefore, for this study a total of 10 honeybee colonies in frame hives in selected two representative experimental sites were used. Those selected honeybee colonies were then further strengthened through provision of supplementary food (sugar syrup in a 2:1 ratio) before executing the experiment and during the experimental periods and were kept under uniform environmental conditions to forage nectar and pollen sources. Before the starting of the experiment, conditions like the presence of adequate brood and drones were checked. Then after, the experiment was done following the scientific procedures of splitting queen-rearing technique. During experimentation, daughter colonies after splitting were kept in the original apiary and the mother colonies were moved some 500 meters away from the apiary for about 25 days until they established their own mature queens. Follow ups, starting from the third day after splitting, were undertaken and less strong and deformed queen cells were removed on the eighth day. Emergency of the queen was also checked on the sixteenth day after splitting. number of queen cells constructed, number of queen larvae developed in to pupae, queen pupae harvested, queens hatched, mated and started laying eggs from parent colonies in the frame, 
number of multiplied honeybee colonies adapted and time of each reproductive pattern were collected, systematically analyzed and interpreted using appropriate statistical tools.

\section{Results and Discussion}

The technique, splitting honeybee colony multiplication, has been started in the zone for the first time by this research group to verify the already tested technology in different areas of the country with top bar hives. Moreover, the prevailing condition in serious colony shortage, facing the area (Wag-Lasta), has also forced the study of this technique in frame hives.

With this experiment, it was possible to understand that, even in areas where honeybee feed shortage is paramount important and prevalence of longer dearth period and absconding is a peculiar characteristic, colony multiplication could be done and used as a means of alleviating serious colony shortage. The most and foremost important thing that we have observed from this experiment is that colony management played a significant role.
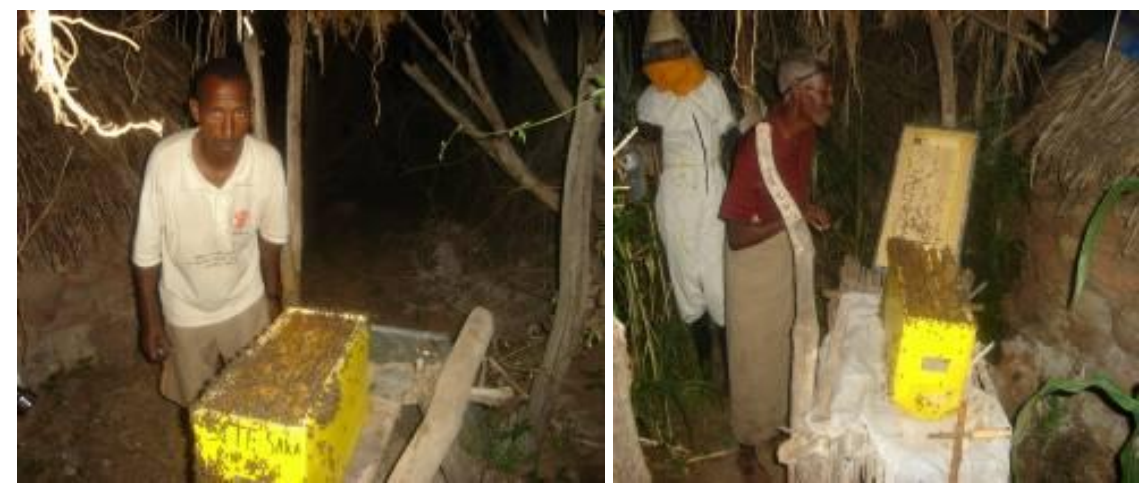

Figure 1: Splitting colony multiplication technique practice at the backyards of the beekeepers

In this experiment, out of the total ten colonies assigned to the technique (splitting) in two representative sites of the study area, $40 \%$ of the splitted colonies have absconded because of serious wax moth infestation pronounced by strong dearth and about $60 \%$ of the colonies were adapted to the splitting technique.

Of the absconded colonies, $30 \%$ of them were mother colonies and the others $(70 \%)$ were daughter colonies. From the results here, it has been confirmed that strong dearth has resulted with harder pest infestation and cause colony absconding. However, serious colony management could be a copping mechanism.

Table 1: Number of honeybee colonies splitted, queen cells developed, adapted and absconded

\begin{tabular}{|c|c|c|c|c|c|c|c|c|c|}
\hline $\begin{array}{c}\text { Total } \\
\text { Beekeepers } \\
\text { Participated }\end{array}$ & $\begin{array}{c}\text { Total } \\
\text { Colonies } \\
\text { Splitted }\end{array}$ & $\begin{array}{c}\text { Total } \\
\text { Daughter } \\
\text { Colonies } \\
\text { Obtained }\end{array}$ & $\begin{array}{c}\text { Total } \\
\text { Colonies }\end{array}$ & $\begin{array}{c}\text { Total Queen } \\
\text { Cells } \\
\text { Developed }\end{array}$ & $\begin{array}{c}\text { Total } \\
\text { Daughter } \\
\text { Colonies } \\
\text { Adapted }\end{array}$ & $\begin{array}{c}\text { Total } \\
\text { Daughter } \\
\text { Colonies } \\
\text { Absconded }\end{array}$ & $\%$ & $\begin{array}{l}\text { Total Mother } \\
\text { Colonies } \\
\text { Absconded }\end{array}$ & $\%$ \\
\hline 10 & 10 & 10 & 20 & 86 & 5 & 5 & 50 & 3 & 30 \\
\hline
\end{tabular}

As a result of this experiment, a very important phenomenon what was observed during the experimental period in the first $6-9$ days after splitting is the local honeybee colonies were able to emerge a total of 86 queen cells (Table 1 and Figure 2) in which 47 of them were from site A (midland) and 39 were from site B (lowland) with an average of 8.6 queen cells in both experimental sites with a maximum and minimum of 15 and 5 queen cells respectively (Table 2). This, in turn, has elaborated that local honeybee colonies have a potential to queen rearing techniques and are active to understand the replacement of missed queens rather than absconding in case of death of queens. And it was also possible to observe that more number of queen cells was developed in mid altitude representing site (A) than the lower altitude representative one. 


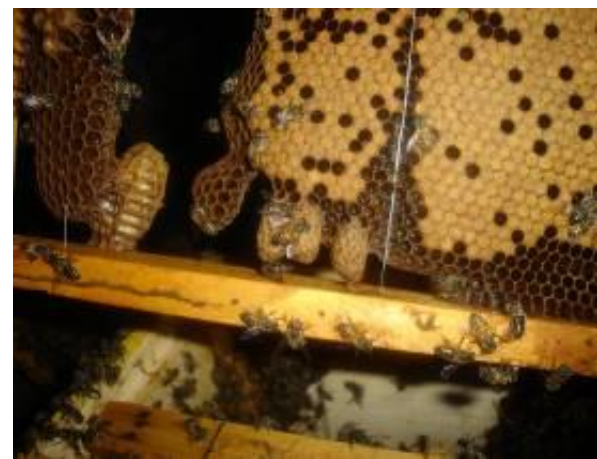

Figure 2: Queen cells developed by daughter colonies

At the end of the experiment, it was confirmed that a total of 8 colonies were absconded. Of these, 1 mother colony and 3 daughter colonies were from location A and 2 mother colonies and 2 daughter colonies were from location B (Table 2). As a result, daughter colonies in the mid altitude had less rate of survival during strong dearth periods and pest infestations than colonies in lower altitude.

Data obtained from experimental colonies before splitting has showed that a total of 46 and $51 \mathrm{~kg}$ of honey was harvested from site A and B with an average productivity of 9.2 and $10.2 \mathrm{~kg}$ per colony per year respectively. Whereas, honey productivity from both colonies in site A and B after splitting was found to be 73 and $89 \mathrm{~kg}$ per colony per year with an average productivity of 14.6 and $17.8 \mathrm{~kg}$ of honey respectively (Table 2).

Table 2: Total queen cells constructed, colonies adapted, absconded and honey produced

\begin{tabular}{|c|c|c|c|c|c|c|c|c|c|c|}
\hline \multirow{2}{*}{$\begin{array}{l}\text { Name of } \\
\text { Participant }\end{array}$} & \multirow{2}{*}{$\begin{array}{l}\text { Date of } \\
\text { Splitting }\end{array}$} & \multirow{2}{*}{$\begin{array}{l}\text { Locati } \\
\text { on }\end{array}$} & \multirow[b]{2}{*}{$A E Z$} & \multirow{2}{*}{$\begin{array}{c}\text { Total } \\
\text { queen } \\
\text { cells } \\
\text { developed }\end{array}$} & \multicolumn{2}{|c|}{$\begin{array}{c}\text { Total colonies } \\
\text { absconded }\end{array}$} & \multirow{2}{*}{$\begin{array}{l}\text { Honey } \\
\text { harvested } \\
\text { before } \\
\text { splitting }\end{array}$} & \multicolumn{3}{|c|}{$\begin{array}{l}\text { Honey harvested after } \\
\text { splitting }\end{array}$} \\
\hline & & & & & $\begin{array}{l}\text { Mothe } \\
\text { r }\end{array}$ & $\begin{array}{l}\text { Daught } \\
\text { er }\end{array}$ & & $\begin{array}{l}\text { Mother } \\
\text { colony }\end{array}$ & $\begin{array}{c}\text { Daught } \\
\text { er } \\
\text { colony }\end{array}$ & Total \\
\hline $\begin{array}{l}\text { Endeshaw } \\
\text { Endalew }\end{array}$ & $\begin{array}{c}11 / 1 / 200 \\
1\end{array}$ & \multirow{5}{*}{ A } & \multirow{5}{*}{$\begin{array}{l}\text { Midlan } \\
\text { d }\end{array}$} & 15 & 0 & 1 & 8 & 12 & 0 & 12 \\
\hline $\begin{array}{c}\text { Mulugeta } \\
\text { Asmare }\end{array}$ & $\begin{array}{c}1271 / 200 \\
1\end{array}$ & & & 7 & 0 & 0 & 7 & 4 & 8 & 12 \\
\hline Getu Molla & $\begin{array}{c}11 / 1 / 200 \\
1 \\
-x y m a-1\end{array}$ & & & 7 & 0 & 1 & 9 & 12 & 0 & \\
\hline Molla Berie & $\begin{array}{c}11 / 1 / 200 \\
1\end{array}$ & & & 5 & 1 & 1 & 10 & 0 & 0 & \\
\hline Tefera Ageze & $\begin{array}{c}11 / 1 / 200 \\
1 \\
\end{array}$ & & & 13 & 0 & 0 & 12 & 18 & 19 & 37 \\
\hline \multirow{2}{*}{\multicolumn{4}{|c|}{$\begin{array}{r}\text { Sub Total } \\
\text { Average per Colony }\end{array}$}} & 47 & 1 & 3 & 46 & 46 & 27 & 73 \\
\hline & & & & $9.4^{-}$ & 0.2 & 0.6 & 9.2 & 9.2 & 5.4 & 14.6 \\
\hline Kinfe Gebeyaw & $\begin{array}{c}26 / 12 / 20 \\
00\end{array}$ & \multirow{5}{*}{ B } & \multirow{5}{*}{$\begin{array}{c}\text { Lowlan } \\
\mathrm{d}\end{array}$} & 8 & 1 & 0 & 9 & 0 & 16 & 16 \\
\hline Hante Gebeyaw & $\begin{array}{c}26 / 12 / 20 \\
00\end{array}$ & & & 5 & 1 & 1 & 8 & 0 & 0 & 0 \\
\hline Tekle Dessie & $\begin{array}{c}26 / 12 / 20 \\
00\end{array}$ & & & 7 & 0 & 1 & 10 & 16 & 0 & 16 \\
\hline $\begin{array}{l}\text { Gebremichael } \\
\text { Gebreselasie }\end{array}$ & $\begin{array}{c}26712 / 20 \\
00\end{array}$ & & & 9 & 0 & 0 & 12 & 15 & 4 & 19 \\
\hline $\begin{array}{l}\text { Worash } \\
\text { Gebeyaw }\end{array}$ & $\begin{array}{c}26712 / 20 \\
00\end{array}$ & & & 10 & 0 & 0 & 12 & 20 & 18 & 38 \\
\hline \multirow{2}{*}{\multicolumn{4}{|c|}{$\begin{array}{r}\text { Sub Total } \\
\text { Averageper Colony }\end{array}$}} & 39 & 2 & 2 & 51 & 51 & 38 & 89 \\
\hline & & & & 7.8 & 0.4 & 0.4 & 10.2 & 10.2 & 7.6 & 17.8 \\
\hline \multicolumn{4}{|c|}{ Grand Total } & 86 & 3 & 5 & 97 & 97 & 65 & -162 \\
\hline \multicolumn{4}{|c|}{ Overall Average per Colony } & 8.6 & 0.3 & 0.5 & 9.7 & 9.7 & 6.5 & 16.2 \\
\hline
\end{tabular}

With this, comparison between honey produced from mother colonies before splitting and produced honey from both mother and daughter colonies after splitting have revealed that honey production after splitting has exceeded the production before splitting with a 27 and $38 \mathrm{~kg}$ of honey yield increase in locations A and B respectively with a total percent increase of 40.12 (Table 3). This could confirm that, splitting is not only able to increase the number of colonies but also the amount of honey produced after splitting. 
Table 3: Honey yield increase and/or advantage as a result of colony splitting

\begin{tabular}{|c|c|c|c|c|c|c|}
\hline \multirow{2}{*}{ Location } & \multirow{2}{*}{$\begin{array}{l}\text { Honey Harvested Before } \\
\text { Splitting }\end{array}$} & \multicolumn{3}{|c|}{ Honey Harvested After Splitting } & \multirow{2}{*}{$\begin{array}{c}\text { Yield } \\
\text { Increase }\end{array}$} & \multirow{2}{*}{$\begin{array}{c}\% \\
\text { Increased }\end{array}$} \\
\hline & & Mother Colony & Daughter Colony & Total & & \\
\hline Tiya & 46 & 46 & 27 & 73 & 27 & 36.99 \\
\hline Saka & 51 & 51 & 38 & 89 & 38 & 42.70 \\
\hline Total & 97 & 97 & 65 & 162 & 65 & 40.12 \\
\hline
\end{tabular}

Productivity data compared between splitted and developed daughter colonies with that of the control colonies from non-participating beekeepers (those which were not splitted) has revealed that honey production from splitted and developed colonies was higher than that of non-splitted colonies.

In this regard, colonies from participant beekeepers have produced a total of $97 \mathrm{~kg}$ of honey only from the mother colonies; whereas colonies from non-participant beekeepers have produced $87 \mathrm{~kg}$ of honey. However, it is believed that the yield difference may have increased if three of the mother colonies from participant beekeepers didn't abscond due to strong pest infestation (wax moth). Moreover, it was also clear that participant beekeepers have a yield advantage of $65 \mathrm{~kg}$ of honey harvested from daughter colonies as a result of splitting (Table 4).

Table 4: Honey production comparison between colonies of participants and non-participants

\begin{tabular}{|c|c|c|c|c|c|}
\hline \multirow{3}{*}{ Location } & \multicolumn{5}{|c|}{ Honey production (kg) } \\
\hline & \multirow[b]{2}{*}{ Before splitting } & \multicolumn{3}{|c|}{ After splitting (Participants) } & \multirow{2}{*}{$\begin{array}{l}\text { Non-Participants } \\
\text { Mother colonies }\end{array}$} \\
\hline & & Mother colonies & $\begin{array}{c}\text { Daughter } \\
\text { colonies }\end{array}$ & Total & \\
\hline A & 46 & 46 & 27 & 73 & 21 \\
\hline B & 51 & 51 & 38 & 89 & 66 \\
\hline Total & 97 & 97 & 65 & 162 & 87 \\
\hline
\end{tabular}

As a result of this technique, participant beekeepers were very happy not only because of the total yield increment but also for having additional honeybee colonies and for the simplicity of the technique to apply. Of course, proper management of honeybee colonies especially before, during and after splitting and strong dearth periods was a paramount importance.

Even though, the technique reduces honey yield soon after splitting, participant and non-participant beekeepers have been convinced that production will progress gradually after the first year of establishment as they have observed the yield advantage of splitting over un-splitted colonies and they understood that this could potentially be a consistent income generating activity even from sale of live bee colonies other than honey in the coming years. Farmers, district experts, agriculture development agents and other relevant stakeholders have encouraged these results and gave very good comments on the relevance of the technique in the area and have suggested that the technology should be transferred to the needy beekeepers through establishment of different small groups be it farmers' research and extension groups or not with a close assistance from the research and extension. They have also complied that the use of such technologies should be considered as an important step to help the increasing demand of honeybee colonies by emerging beekeepers in the area.

Based on the results that was obtained from this technique and the opinions, the technique have been transferred to the farmers' research and extension groups (containing 15 members). In this activity, the technique was effective to enable the splitted colonies to grow faster and transferred to the standard frame hive within one month time, which was expected to stay in the nuclei hive, at least, up to the next flowering period. Two months later, interestingly, these colonies have produced considerable amount of honey and all the splitted colonies and daughter colonies have survived the strong dearth period in the lowland.

The technique has been also applied to PSNP+ project (an NGO involved in the area) beneficiary beekeeper farmers in 6 localities with strong assistance from the research group. Accordingly, the data obtained from the beneficiary beekeeping farmers themselves have revealed that they have splitted 21 colonies and only one of the daughter colonies has absconded (Table 5). This, therefore, could confirm that colony multiplication using splitting technique can be used in the area having in mind that dearth period supplementation and proper colony management are the basic activities to be carried out.

Table 5: Colony multiplication results obtained from some beneficiary beekeeping farmers of an NGO

\begin{tabular}{cccccc}
\hline $\begin{array}{c}\text { Total colonies } \\
\text { splitted }\end{array}$ & $\begin{array}{c}\text { Total queen cells } \\
\text { developed }\end{array}$ & $\begin{array}{c}\text { Average queen cells } \\
\text { per colony }\end{array}$ & $\begin{array}{c}\text { Total daughter } \\
\text { colonies adapted }\end{array}$ & $\begin{array}{c}\text { Total mother colonies } \\
\text { adapted }\end{array}$ & $\begin{array}{c}\text { No. colonies } \\
\text { absconded }\end{array}$ \\
\hline 21 & 187 & 8.9 & 20 & 21 & 1 \\
\hline
\end{tabular}


Currently, to the technique has widened up through demonstration and evaluated for its contribution to the household income of the beekeeping farmers in the area within different farmers' research and extension groups. From the experiment and personal observations, it had been confirmed that the activity shall be appropriately implemented during the potential onset of flowering season (i.e. starting from mid of August to last week of August or some 2-3 days later in lower altitudes and from last week of August to second week of September in higher altitudes) of the study area with strong mother colonies and further supplementary feeding being a necessary colony management activity to be used as a vital kit for successful queen rearing in the area.

\section{Conclusion and Recommendations}

Even if the objective of the experiment was to verify and evaluate efficiency of the technique in our local conditions, it was confirmed that out of the total colonies in both locations, about $40 \%$ have absconded 6 months after splitting only due to wax moth infestation resulted from strong dearth and about $60 \%$ of them were adapted. It has been understood also that strong dearth might brought pest infestation harder and resulted with considerable colony absconding.

However, even in areas, where honeybee feed shortage is paramount important and prevalence of long dearth period and absconding is a peculiar characteristic to the beekeeping sub sector, colony multiplication could be an activity to be carried out and used as a means of alleviating serious colony shortage. Of course, colony management is the most and foremost important thing that we have to understand.

From the experiment, the local honeybee colonies were found to emerge appropriate number of queen cells in both experimental sites. This, in turn, has elaborated that local honeybee colonies have a potential to queen rearing techniques and are active to understand the replacement of missed queens rather than absconding in case of death of queens in the area.

Total number of queen cells developed from daughter colonies, during the first $6-9$ days after splitting, have indicated that local honeybee colonies, even they have twisted production problems, more number of queen cells could be developed and have a possibility of having more than 8 colonies splitted from a single mother colony in the area.

Regarding yield advantage from colony splitting, honey produced from the mother colonies before splitting and produced honey from both mother and daughter colonies after splitting have revealed that honey production after splitting has overcome the production before splitting with a $40.12 \%$ yield increase in both sites. Productivity comparisons among participant and non-participant beekeepers' colonies have also revealed that participant beekeepers have benefited from the technology that they have used over the non-participant beekeeping farmers. This, therefore, has confirmed that, even if splitting could decrease honey production at that particular period, colonies were able to compensate in the coming honey flow season and afterwards.

Suggestions from farmers and stakeholders have encouraged participant beekeepers for further use of the technique and helped the transfer of the technology to neighboring beekeeping farmers. The use of such technologies should also be considered as an important step to backup the increasing colony shortage and increasing colony demand in the area.

Finally, based on the results of the experiment, it can be recommended that

$\oplus$ Splitting colony multiplication technique could be further applied and utilized targeting increased number of honeybee colonies to satisfy the increasing colony demand under farmers' condition

$\oplus$ Strong training provision on practical queen rearing techniques and preconditions shall not be forgotten when thinking of colony multiplication in the area

4 Scaling up could be done through different beekeeping farmers and small interest/business groups in different localities across existing production systems in and around the area

$\oplus$ The use of strong mother colonies or strengthening of colonies before splitting through intensive supplementation shall not be kept aside

$\oplus$ The activity should also be implemented during the potential onset of flowering season (starting from mid of August to first week of September in lower altitudes and from last week of August to second week of September in higher altitude areas)

$\oplus$ The government should focus on awareness creation for the best of technology transfer, organization of small interested/business groups, supporting and encouraging the activity and the groups and linking the system, even, to marketing of live colonies 


\section{References}

[1]. Abebe J., 2008. Honeybee Floral Phenology, Pollen Potential, Honey Quality and Management of Beekeeping in three Agroecologies of Sekota Woreda, Wag-Himra Zone, Amhara Region, Ethiopia, Mekelle University, Ethiopia

[2]. Nuru A. and Dereje W., 1999. Responses of Ethiopia honey bees to different queen rearing techniques. Proceeding of the 7th annual conference of the Ethiopian society of animal production (ESAP) held in Addis Ababa, Ethiopia, 26-27 May 1999. pp 125-132

[3]. Jim C. and Jeanne M., 1984. Queen Rearing: beekeeper's primer, issue No-87. http/www.motherearthnews.com. (Accessed on December 28, 2006 at 1:43 pm)

[4]. Jay S., 1923. Queen Rearing Simplified, THE A.I. ROOT COMPANY Medina, Ohio, USA

[5]. Dan C., 2006. Queen Management Notes, New Hampshire Bee Meeting, South Deerfield, Massachusetts, USA

[6]. Graham J., 1992. The hive and the honey bee, Dadant and Sons printing, Hamilton, Illinois, USA

[7]. Laidlaw H. and Eckert J., 1962. Queen Rearing, University Press, Berkly, California, USA

[8]. Snelgrove L., 1981. Queen Rearing, Snelgrove and Smith publisher, Avon, UK 